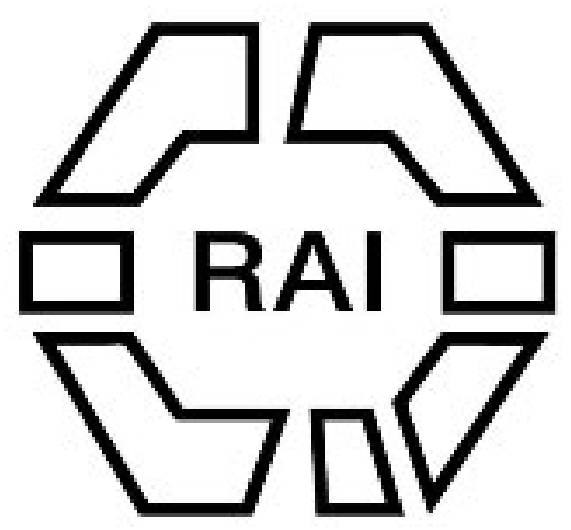

A Hindu Prophetess.

Author(s): M. J. Walhouse

Source: The Tournal of the Anthropological Institute of Great Britain and Ireland, Vol. 14 (1885), pp. 187-192

Published by: Royal Anthropological Institute of Great Britain and Ireland

Stable URL: http://www.jstor.org/stable/2841857

Accessed: $15 / 06 / 2014$ 18:38

Your use of the JSTOR archive indicates your acceptance of the Terms \& Conditions of Use, available at http://www.jstor.org/page/info/about/policies/terms.jsp

JSTOR is a not-for-profit service that helps scholars, researchers, and students discover, use, and build upon a wide range of content in a trusted digital archive. We use information technology and tools to increase productivity and facilitate new forms of scholarship. For more information about JSTOR, please contact support@jstor.org. 
the "mesio-distal molar length," was an important one, and conveniently made upon the living subject, though unfortunately the other faotor of the Professor's "dental index" must be otherwise inferred during life. Perhaps the most interesting point brought out by the statistics was that the European races were really within one group-the Microdont; this fact bearing upon the theories as to the pathological conditions presented in dental crowding and certain forms of irregularities. It was highly important to know something of the distribution of variations within the range of the groups averaged, and especially of the frequency of exceptional ones at the limits.

Mr. LEWIS inquired whether the teeth in all races were of the same proportions, or nearly so, as it seemed that the observations of the President were based solely on the space occupied by the three molars in line. He congratulated the President on having taken up a line of investigation which was apparently not only new, but likely to lead to important results.

The following paper was read by the author:-

\section{A Hindu Prophetess.}

By M. J. Walhouse, Esq.

ABout five-and-thirty years ago, in 1850 or 1851, when the Company still bore rule, I was posted in one of the Madras provinces on the borders of Mysore, a jungly region, thinly sprinkled with villages; and one day received information from a Tahsildar, or native magistrate, that a certain woman, credited with supernatural powers, was causing terror and annoyance in his neighbourhood from the belief that she could inflict cholera, so that people were leaving their villages on her approach. I directed him to send her to me, but he replied that none of his peons, i.e., native policemen, dared meddle with her, and requested me to send some of my own. So I despatched two constables, both Mussulmans, who despised all Hindu superstitions, and they returned with her in custody, for she made no resistance to authority directed by an European. She proved to be a woman somewhat over thirty, rather tall, of composed; reflective demeanour, with no assumption of any unusual powers. She had a long thin visage, a fixed dreamy gaze, a slow, measured way of speaking. She belonged to the agricultural class, and was commonly spoken of as $A m m \bar{a} l$, i.e., Lady or Madam; her name was Nágamani, or "Snake-necklace," an allusion to the ornament worn by Siva. Her only attendants were a large black monkey

02 
and an idiot boy. I could not find that she had any system of extortion by threats or striking terror, but that she proceeded from village to village in a manner somewhat inconvenient to the people, for when she wished to move on she signified her intention to the headman of the village, who at once supplied bearers, who carried her in a sort of litter in which she travelled, cf course without payment, and none dared refuse, or leave her without permission. Whilst she stayed in a village the people would bring her food, and often seek her judgment on family matters and quarrels, disputes respecting land, caste, and questions interesting to villagers. She would give a brief decision, and intimate that the curse of the god would follow disobedience, and it was affirmed and believed that some mishap was always found to result from neglect of her award. Losing parties were naturally galled, and after some stay in the village any accidents, cases of cattle-sickness and the like, came to be attributed to her displeasure, and hence, though she was not accustomed to use threats, the villagers were generally glad to see their visitor depart.

I told her that these circuits and visitations could not be permitted, and required her to give them up. She replied quictly but steadily that she could not without the sanction of the god. There was a good deal of sickness about; harsh dealing with her might have had bad effect, and there was indeed no special ground for it. So I ordered her to be kept in confinement as a vagabond for the present. She obeyed passively, only saying that whilst confined no food should pass her lips. The jailor, a grim, fanatical old Mussulman, thoroughly despising all infidel idolatries and superstitions, asked me what food she was to have; she had a good deal of money with her, and a large amount of bits and pieces of silver, so I told him to provide her with good food, as she could pay for it, and to take note whether she ate any, mentioning what she had said. The old fellow grinned scornfully and said she should not deceive him. After about a week, however, he came to me and said, "Sir, the woman eats nothing; not a grain of her food is touched." I answered, "She is cheating you in some way: watch well. You have spies, see that no other food is conveyed to her." But after a tew more days he again came and declared that she still ate nothing; that she made no complaint, did not appear to suffer at all, and that he was certain no other food reached her, unless through the Shaitan! So I went to see her, and found her looking just the same, and apparently quite unaffected by more than a fortnight's fast. Being then alone with her, and observing she was less disposed to be reserved, I desired her to give an account of herself and her way of life. Raising her eyes 
with a far-away visionary look she slowly answered that when a girl, near Seringapatam, she was passing through a jungle when she met the god Siva face to face! "He entered my hosom," she said. "He abides in me now ; my blessing is lis blessing, and my curse is his curse! He speaks through me : the village people ask me questions. I know nothing of the matters. He speaks with my tongue: it is he who commands!" "Has he left you now that you are in prison?" I asked. "He has given me no order," she said ; " he is my strength: when he desires I shall go." She spoke in a calm, unimpassioned way, as one thoroughly assured. She seemed to consider herself freed from the oidinary rules and observances of Hindu life, which is at almost every hour governed by ceremonials connected with astrolosy and the changes of the moon : the cunstantly recurring fasts and festivals were disregarded by her. Those who know Hindu inner life will understand how great such heresy would seem; but she did not pretend to be a devotee, nor to any knowledge of magic and spells in which Hindus in every rank firmly and abjectly believe, though such pretence would certainly have increased her influence. There is nothing that more colours Hindu life than the belief in the efficacy of Mantras - certain forms of prayer or powerful words-by which all the changes and relations of life may be influenced for good or ill, and the gods even may be bound. This idea runs through all Indian literature, and operates in all business and undertakings. Only Brahmans and devotees can properly know and use these powerful words, and they are forbidden to women; but vulgar magicians often pretend to their knowledge. This woman was said to use one Mantra, the Panchāxăram, or Five-lettered Spell. Laying her hand on a string of the rough round excrescences commonly called Brahming beads-properly Riudrākshas, i.e., eyes of Siva, because said to have been tears wept by him-she would utter over them the words Nama Sivaya (Salutation to Siva), whereby the beads became endowed with fortunate properties. The Brahmans must have regarded this much as a priest would regard a layman pronouncing the absolution, for it is a great and holy Mantra, but they held their peace; once, indeed, in a well-known Hindu poem a princess is recorded to have learnt and used it, with miraculous effect.

However, not to be tedious, after this woman had been in confinement some five weeks, during which she conducted herself very quietly, and it could never be discovered that any food passed her lips, it seemed unadvisable and useless to detain her, so I proposed to send her back to her ow'n neighbourhood of Seringapatam. She acquiesced, and I caused the many pieces of silver she had to be sold, gave her the proceeds, nearly four 
hundred rupees, and sent her across the Mysore border with her monkey and the idiot boy, who had meanwhile been well cared for by the villagers. It was not a very safe country to travel through, but her reputation was a sufficient safeguard, and I never heard of her afterwards.

It seemed to me that her case enabled one in some measure to realise those stories of women of commanding influence who have from time to time appeared in all ages and countries; and amid cultivated, no less than rude and barbarous, races exercised a mysterious power, and left an impression that time and change failed to efface. Such were those problematical personages the Sibyls-vessels of the Deity, as the word is said to implywhether they numbered four or ten, for all traditions concerning them are indistinct and cloudy: certain, however, it is that the writings of one of them were treasured through the early centuries of Rome, and solemnly consulted in all emergencies and the verses still extant, called Sibylline, were held in reverence by the early Church, and quoted concurrently with Scripture. ${ }^{1}$ On the walls of the famous Sistine chapel in the centre of Catholic Christendom the mightiest genius of modern art has depicted the Sibyls seated with the great prophets of the Law in sublime contemplation of the unfolding of the Christian dispensation. In the old world for many ages the Pythian priestesses were held in the highest reverence. That long line of venerable and august virgin prophetesses is one of the strangest and least understood phenomena of antiquity. All we know is that, like the Sibyls, the god was held to possess and speak through them, when inspired by the mysterious exhalation. They too must have been women of that strange personal authority that forces men to listen and obey. Amid the acutest and most civilised nations of antiquity their reputation was maintained for ages. All sought their counsel, States and kings as well as individuals, and it is not probable such a state of things would have continued without general success, or even with much failure; nor is it to be supposed, according to modern popular notions, that all was trickery and collusion.

"Never from lips of cunning fell,

The thrilling Delphian oracle."

In Holy Writ, too, we read (Judges iv) that "Deborah the prophetess judged Israel; and the children of Israel came up to her for judgment" as she sat under her palm-tree; and with triumphant inspiration she sang that great ode of victory and exultation over the defeated King of Canaan.

${ }^{1}$ Dies iræ-dies illa.

Solvet sæclum in favilla,

Teste David cum Sibylla. 
No less, too, the rude and warlike tribes that journeyed from the German forests to overthrow and destroy the civilisation of the Roman world acknowledged the mystic influence of prophetic women, and regarded them even as goddesses. Those hugelimbed warriors, who lived but for war and battle, bowed with unbounded reverence to the Alruna maidens, who from their retreats in caverns or river-islands delivered the mandates of the gods and inspired unconquerable courage. In the reign of Vespasian, one of them, called by Roman historians Veleda, by her inspiring prophetic utterances incited her countrymen to withstand for a considerable period the advance of the Romans on the Rhine. A distorted tradition of those awe-inspiring women, in a malignant and evil aspect, may have been in Shakespeare's mind when he drew the weird sisters-no vulgar witches in his view, but posters of the sea and land, commanding the winds and tempests and stirring up the evil passions of men to deadly issues; and Walter Scott has pictured the last descendant of the Alruna prophetesses of the North in Norna of the Fitful Head, the stately old Reimikennar, who knew the runes, could stay the tempest, look into the future, and whose ban was universally dreaded.

It seems of some anthropological interest to note the appearance from time to time in widely separated ages, lands, and races, of remarkable women, distinguished by the same general characteristics, claiming the same preternatural experiences and powers, and leaving a lasting impression on popular remembrance. Still the traditions of them convey picturesque and striking images:- the Sibyl, royally arrayed, in her cavern, overladen, and striving with frenzied action to shape the divine message into utterance; the Pythia, long-robed and crowned with the mystic fillets of wool, seated on the tripod, awaiting the inspiration of the god; and the stately Veleda, shut in her tower by the Rhine, invisible to all, except the chosen kinsman who received and imparted her commands (Tacitus, "Hist.," iv, 65).

Some may have noticed in the gardens of the Luxembourg the fine statue in which one of the best French sculptors has embodied his conception of this grand seeress. I will conclude with one of these weird women, once famous in England, and hardly yet forgotten. In 1686 a curious pamphlet was published in London giving an account of Mother Shipton, "the Yorkshire prophetess." She was born in the reign of Henry VII, and, the chronicle says, "got a name far and near for a cunning woman, or a woman of the foresight, so that her words began to be counted." She was of tall and somewhat forbidding presence, and vulgar talk soon invested her with the traditional witch-attributes and ascribed her birth to diabolical parentage. It is recorded 
that not only private persons resorted to her, but "people of the greatest quality;" amongst them Cardinal Wolsey, of whom she said, when it was reported that he intended to retire and live at York, that he should never come thither, and indeed when within sight of York he was suddenly recalled by the king's messengers, and died soon after at Leicester. Like the Pythia she at times delivered obscure prophecies in rough verses, several of which, it is recorded, were taken down by the Abbot of Beverley, and kept in the Abbey till the dissolution. Some have been handed down, and held to foreshadow the Great Fire of London, the reign of Elizabeth, the execution of Charles I, and other public events. Not long ago a series of clever forgeries attributed to her were put into circulation. During her long life this "famous prophetess and Sibyl," as she is termed, appears to have maintained her reputation, and died at the age of seventy-three on a day predicted by herself. She left a deep impression on popular memory, not yet effaced, and even now shares with royalty and great personages the distinction of being adopted as a sign for inns,--there is a well-known example here in northern London,--and still when the East-end mechanic goes on a holiday in early summer entomologising, as many do, he looks in the hay-fields for a day-flying moth, in the lines and marks on whose wings the features of a human face with long crooked nose and chin are thought to be discerned, and calls it "the Mother Shipton."

The following paper was read by the author, and illustrated by the exhibition of a large collection of implements :-

\section{On certain less familiar Forms of Paleolithic Flint IMPLEMENT's from the GraveL at READING.}

\section{By O. A. Shrubsole, F.G.S.}

\section{[With Plate XI.]}

THE purpose of the present paper is to draw attention to some of the less familiar forms of palæolithic implements. As, however, most of the specimens to which reference will be made have been obtained from the high-level gravel of the Thames valley near Reading, it may be convenient in the first instance briefly to refer to that gravel, and to the conditions under which the implements have occurred, in order to arrive at some approximate idea of their geological age. I do not in any way 